Jurnal Keperawatan Silampari

Volume 4, Nomor 1, Desember 2020

e-ISSN: 2581-1975

p-ISSN: 2597-7482

DOI: https://doi.org/10.31539/jks.v4i1.1449

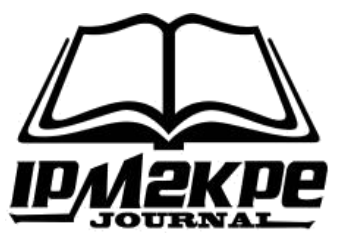

\title{
PENGETAHUAN DAN SIKAP ANAK TENTANG MAKANAN JAJANAN SEHAT MELALUI PERMAINAN ULAR TANGGA
}

\author{
Oslida Martony ${ }^{1}$, Alfira $^{2}$, Eliska $^{3}$ \\ Politeknik Kesehatan Kementrian Kesehatan Medan ${ }^{1}$ \\ Universitas Islam Negeri Sumatera Utara ${ }^{2,3}$ \\ Olisda64@gmail.com ${ }^{1}$
}

\begin{abstract}
ABSTRAK
Tujuan penelitian ini untuk mengetahui pengetahuan dan sikap anak tentang makanan jajanan sehat melalui permainan ular tangga di kecamatan lubuk pakam. Penelitian ini merupakan penelitian kuantitatif dengan rancangan quasy eksperimen two group pretestposttest design. Hasil penelitian menunjukkan bahwa dengan menggunakan uji statistik diperoleh nilai $\mathrm{p}=0,000<0,05$. Berdasarkan hasil pretest dan posttest terhadap 54 siswa, didapat rata-rata perubahan pengetahuan sebelum intervensi sebesar 12,8 dan sesudah intervensi sebesar 15,5, dan perubahan sikap rata-rata sebelum intervensi sebesar 10,2 dan sesudah intervensi sebesar 12,8. Simpulan, adanya pengaruh penyuluhan permainan ular tangga tentang makanan jajanan sehat terhadap pengetahuan dan sikap pada anak sekolah dasar.
\end{abstract}

Kata Kunci : Jajanan Sehat, Pengetahuan, Sikap, Ular tangga

\begin{abstract}
This study aimed to determine the knowledge and attitudes of healthy snack children through snake and ladder games in Lubuk Pakam sub-district. This research is a quantitative study with a quasi-experimental design of two groups of the pretest-posttest system. The results showed that by using the statistical test, the value of $p=0.000<0.05$. Based on the pretest and post-test results on 54 students, the average change in knowledge before the intervention was 12.8, and the closest intervention was 15.5. The shift in attitude before the intervention was 10.2, and after the intervention was 12.8. In conclusion, there is the influence of snake and ladder game counseling on healthy snack foods on elementary school children's knowledge and attitudes.
\end{abstract}

Keywords: Healthy Snacks, Knowledge, Attitudes, Snakes, and ladders

\section{PENDAHULUAN}

Makanan yang sehat merupakan bagian yang penting bagi proses pertumbuhan dan perkembangan anak serta sebagai dasar pemeliharaan kesehatan baik bagi anak, maupun badi orang dewasa. Sejalan dengan perkembangan zaman, semakin banyak bahan makanan yang menggunakan bahan kimia dalam makanan dan jajanan. Permasalahan keamanan 
jajanan sehat pada anak usia sekolah menjadi suatu masalah global terutama di Indonesia yang perlu mendapatkan perhatian utama, karena dalam jajanan memegang peran penting untuk memberikan asupan energi dan zat gizi pada anak usia sekolah. Anak anak seringkali menjadi korban dari makanan atau jajanan sekolah karena mereka belum memiliki pengetahuan yang cukup tentang bagaimana mengenali jajanan yang aman. Makanan jajanan merupakan sesuatu yang tidak terpisahkan dari kehidupan anak sekolah dasar. Makanan jajanan yang dijual oleh pedagang kaki lima atau disebut street food menurut FAO (Food and Agriculture Organization) didefinisikan sebagai makanan dan minuman yang dipersiapkan dan dijual di jalanan dan di tempat-tempat umum yang langsung dikonsumsi tanpa pengolahan atau persiapan lebih lanjut (Agustini et al., 2019).

Pada temuan Badan Pengawas Obat dan Makanan (BPOM) sebanyak 48\% jajanan anak tidak memenuhi syarat keamanan gan karena mengandung bahan kimia yang berbahaya serta cemaran mikrobiologi, kebiasaan dalam mengkonsumsi makanan kurang sehat memiliki resiko lebih besar terkenanyapenyakit yang sering terjadi pada anak yaitu diare, keracunan, demam, pusing, dan penyakit infeksi lainnya akibat imunitas yang menurun. Laporan Direktorat Suveilan dan penyuluhan keamanan pangan BPOM menunjukkan di seluruh Indonesia telah terjadi kejadian luar liasa (KLB) keracunan makanan sebanyak 164 kejadian di 25 provinsi yang mencakup 7.366 kasus dan 51 diantaranya meninggal dunia (Oktaviani et al., 2020).

Pengetahuan yang baik diharapkan dapat mempengaruhi konsumsi makanan yang lebih baik. Pengetahuan termasuk didalamnya pengetahuan gizi dan jajanan yang dapat diperoleh melalui pendidikan formal maupun informal terkhususunya pada anak usia sekolah dimana anak belum mengerti pengetahuan tentang jajanan sehat, makanan atau jajanan yang dipikir sehat menurut mereka belum tentu makanan tersebut sehat di konsumsi, Hal ini dapat terjadi karena kurangnya pengetahuan dan sikap anak mengenai makanan jajanan yang sehat dan aman untuk dikonsumsi. Diperlukan pendidikan kesehatan untuk menanamkan kebiasaan hidup sehat pada siswa yaitu salah satunya dengan media terapi salah satunya untuk meningkatkan pengetahuan dan sikap anak usia sekolah dengan menggunakan terapi bermain ular (Rizqi \& Sartika, 2020).

Penelitian yang dilakukan Rizqi \& Sartika (2020) menunjukkan bahwa ada peningkatan pengetahuan jajanan sehat secara signifikan pada kelompok intervensi yang diberikan media tebak gambar jajanan sehat. Ada perbedaan pengetahuan jajanan sehat secara signifikan antara kelompok intervensi dengan kelompok kontrol.

Sejalan dengan penelitian Septiana \& Suaebah (2019) ditemukan peningkatan pengetahuan dari sebelum diberikan media kartu bergambar sebesar 89,6 menjadi 97,4. Ada perbedaan nilai pengetahuan sebelum dan sesudah intervensi menggunakan media kartu bergambar $(\mathrm{p}<0,05)$.

Terapi bermain merupakan terapi yang cukup efektif menekan angka kecemasan pada pasien yang menjalani hospitalisasi. Bermain dapat membuat anak terlepas dari ketegangan dan stres yang dialaminya. Salah satu terapi bermain yang sesuai pada anak usia pra sekolah adalah jenis permainan skill play, dimana permainan lebih banyak menggunakan kemampuan motoriknya. Salah satu permainan skill play yang banyak digunakan adalah bermain ular tangga, Permainan ular tangga merupakan salah satu mainan rekreasi ringan yang cukup populer di Indonesia di samping mainan papan lain seperti monopoli, ludo, dam, dan halma. Ular tangga menjadi bagian dari permainan tradisional di Indonesia 
meskipun tidak ada data yang lengkap mengenai kapan munculnya permainan tersebut. Permainan edukatif ular tangga adalah media penyuluhan yang dapat meningkatkan pengetahuan anak sekolah. Permainan ini merupakan permainan yang menyenangkan sehingga anak tertarik untuk belajar sambil bermain, ular tangga dapat membantu aspek perkembangan kecerdasan bermain ular tangga membuat permainan ini menjadi sangat populer di masyarakat. Permainan ini ringan, sederhana, mendidik, menghibur dan sangat interaktif jika dimainkan bersama-sama (Olin et al., 2020).

Sejalan dengan penelitian Suryaningsih \& Naviati (2019) setelah dilakukan pendidikan kesehatan dengan media permainan ular tangga sebagian besar tindakan responden menjadi baik. Hal tersebut sesuai dengan teori yang menyatakan bahwa proses perubahan perilaku dipengaruhi oleh umur dan kemampuan akademiknya. Umur responden yang dalam tahapan perkembangan operasional konkret yang merupakan golongan umur yang peka dan mudah menerima informasi serta ditanamkan kebiasaan baik.

Pada penelitian sebelumya menggunakan permainan ular tangga standar. Namun dalam penelitian ini konsep bermain ular tangga menggunakan makanan jajanan sehat (gizi seimbang).

\section{METODE PENELITIAN}

Penelitian ini menggunakan rancangan penelitian quasi-experimental one group prepost test design. Populasi penelitian ini adalah anak sekolah dasar kelas 4 dan 5 SD Swasta Muhammadiyah yang berjumlah 54 orang. Pengambilan sampel pada penelitian ini dilakukan dengan teknik total sampling, dikarenakan kelas 4 dan kelas 5 lebih mudah memahami informasi yang disampaikan, dan siswa kelas 6 sudah mengikuti Ujian Nasional pada anak SD Swasta Muhammadiyah Kec. Lubuk Pakam,

Intervensi diberikan pada kelompok eksperimen yaitu edukasi tantang makanan jajanan sehat melalui bermain ular tangga. Penelitian ini menggunakan uji $t$-dependent. Uji $t$-dependent digunakan untuk melihat pengaruh terhadap kelompok yang datanya saling mempunyai ketergantungan saling berhubungan. Waktu penelitian dilakukan pada tanggal 13 Januari - 26 Februari 2020 di SD Swasta Muhammadiyah Kecamatan Lubuk Pakam. Untuk menilai pengetahuan dan sikap digunakan lembar kuesioner.

\section{HASIL PENELITIAN Analisa Univariat Karateristik Responden}

Tabel. 1

Distribusi Jenis Kelamin

\begin{tabular}{llcc}
\hline No & Jenis Kelamin Sampel & \multicolumn{2}{l}{ Hasil Analisis } \\
\hline & & F & $\%$ \\
\hline 1 & Laki-Laki & 28 & 51,9 \\
2. & Perempuan & 26 & 48,1 \\
\hline
\end{tabular}

Data Statistik : 2019 
Berdasarkan tabel 1, pada karakteristik jenis kelamin sebagian besar adalah laki-laki yaitu sebesar 51,9\%.

Tabel. 2

Distribusi Umur

\begin{tabular}{lccc}
\hline No & Umur Sampel & \multicolumn{2}{c}{ Hasil Analisis } \\
\hline & & F & $\%$ \\
\hline 1 & 9 & 2 & 3,7 \\
2 & 10 & 18 & 32,1 \\
3 & 11 & 25 & 44,6 \\
4 & 12 & 9 & 16,1 \\
\hline
\end{tabular}

Data Statistik : 2019

Berdasarkan tabel 2 pada distribusi umur sampel bahwa responden paling banyak berumur 11 tahun sebesar 44,6\%.

Tabel. 3

Distribusi Frekuensi Pengetahuan

\begin{tabular}{lcccc}
\hline & Sebelum & \multicolumn{2}{c}{ Sesudah } \\
\hline Pengetahuan & Frekuensi & $\%$ & Frekuensi & $\%$ \\
Tinggi & 21 & 38.9 & 51 & 94.4 \\
Sedang & 33 & 61.1 & 3 & 5.6 \\
Rendah & 0 & 0 & 0 & 0 \\
Total & 54 & 100.0 & 54 & 100.0 \\
B & & & & \\
\hline
\end{tabular}

Data statistic (2019)

Berdasarkan tabel 3 menunjukkan bahwa nilai skor pengetahuan siswa sebelum intervensi sebagian besar dengan kategori sedang, yaitu sebanyak 33 siswa $(61,1 \%)$ dan sesudah intervensi sebagian besar dengan kategori tinggi 51 siswa $(94,4 \%)$.

Tabel. 4

Distribusi Frekuensi Sikap

\begin{tabular}{lcccc}
\hline \multirow{2}{*}{ Sikap } & \multicolumn{2}{c}{ Sebelum } & \multicolumn{2}{c}{ Sesudah } \\
& Frekuensi & $\%$ & Frekuensi & $\%$ \\
\hline Baik & 46 & 85,2 & 54 & 100 \\
Buruk & 8 & 14,8 & 0 & 0 \\
\hline Total & 54 & 100.0 & 54 & 100.0 \\
\hline
\end{tabular}

Berdasarkan tabel 4 menunjukkan bahwa nilai skor sikap siswa sebelum intervensi sebagian besar dengan kategori baik, yaitu sebanyak 46 siswa $(85,2 \%)$ dan sesudah intervensi 54 siswa $(100 \%)$. 


\section{Hasil Analisis Bivariat}

Tabel. 5

Skor Pengaruh Permainan Ular Tangga Tentang Makanan Jajanan Sehat Terhadap Pengetahuan Dan Sikap Pada Siswa

\begin{tabular}{lcccc}
\hline & \multicolumn{2}{c}{ Sebelum } & \multicolumn{2}{c}{ Sesudah } \\
\hline \multicolumn{1}{c}{ Variabel } & Mean & Standar & Mean & $\begin{array}{c}\text { Standar } \\
\text { Deviasi }\end{array}$ \\
\hline Pengetahuan & 12,8 & 1,87 & 15,5 & 2,23 \\
Sikap & 10,2 & 2,4 & 12,8 & 1,72 \\
Uji Statistik & $\mathrm{P}=0,000$ & & & \\
& $\mathrm{p}<0.05$ & & & \\
\hline
\end{tabular}

Berdasarkan tabel 5 hasil uji statistic diperoleh nilai $\mathrm{p}=0,000<0,05$ yang menunjukkan adanya pengaruh permainan ular tangga tentang makanan jajanan sehat terhadap pengetahuan dan sikap pada anak sekolah dasar, hal ini didukung oleh data dari 54 siswa anak sekolah dasar yang melakukan pre-test dan post-test didapat rata-rata perubahan pengetahuan sebelum intervensi sebesar 12,8 dan sesudah intervensi sebesar 15,5, dan perubahan sikap rata-rata sebelum intervensi sebesar 10,2 dan sesudah intervensi 12,8.

\section{PEMBAHASAN}

\section{Nilai Pretest dan Posttest Pengetahuan Responden}

Hasil penelitian menunjukkan bahwa nilai skor pengetahuan siswa sebelum intervensi sebagian besar dengan kategori sedang, dan sesudah intervensi sebagian besar dengan kategori tinggi.

Sejalan dengan penelitian Rizqi \& Sartika (2020) menunjukkan bahwa ada peningkatan pengetahuan jajanan sehat secara signifikan pada kelompok intervensi yang diberikan media tebak gambar jajanan sehat $(\mathrm{p}<0,05)$. Ada perbedaan pengetahuan jajanan sehat secara signifikan antara kelompok intervensi dengan kelompok kontrol $(\mathrm{p}<0,05)$. Pendidikan gizi dengan metode menggunakan media tebak gambar dapat meningkatkan pengetahuan mengenai jajanan sehat pada siswa sekolah dasar.

Pengetahuan awal seseorang sebelum menerima intervensi menentukan seberapa tinggi kenaikan skor pengetahuan setelah intervensi diberikan. Peningkatan pengetahuan sering dianggap menjadi langkah pertama dalam mempengaruhi perilaku kesehatan (Rosita, 2017).

Penelitian yang dilakukan oleh Nur \& Duanita (2019) menunjukkan peningkatan nilai pengetahuan dan sikap subjek setelah dilakukan penyuluhan yang kemudian setelah dianalisis secara statistic peningkatan yang terjadi adalah signifikan $0,000(\mathrm{p}<0,05)$.

Pengetahuan yang baik diharapkan dapat mempengaruhi konsumsi makanan yang lebih baik. Pengetahuan termasuk didalamnya pengetahuan gizi dan jajanan yang dapat diperoleh melalui pendidikan formal maupun informal terkhususunya pada anak usia sekolah dimana anak belum mengerti pengetahuan tentang jajanan sehat, makanan atau jajanan yang dipikir sehat menurut mereka belum tentu makanan tersebut sehat di konsumsi, Hal ini dapat terjadi karena kurangnya pengetahuan dan sikap anak mengenai 
makanan jajanan yang sehat dan aman untuk dikonsumsi. Diperlukan pendidikan kesehatan untuk menanamkan kebiasaan hidup sehat pada siswa yaitu salah satunya dengan media terapi salah satunya untuk meningkatkan pengetahuan dan sikap anak usia sekolah dengan menggunakan terapi bermain ular (Rizqi \& Sartika, 2020).

\section{Nilai Pretest dan Posttest Sikap Responden}

Hasil penelitian menunjukkan bahwa terjadi peningkatan jumlah responden dengan nilai skor sikap siswa sebelum intervensi sebanyak 46 siswa dan sesudah intervensi 54 siswa $(100 \%)$.

Sejalan dengan penelitian Nur \& Duanita (2019) didapatkan nilai rata-rata untuk skor sikap sebelum penyuluhan jajanan sehat adalah 43,70 dan nilai rata-rata untuk skor pengetahuan setelah penyuluhan jajanan sehat adalah 48,18. Dari hasil tersebut menunjukkan bahwa ada peningkatan sikap siswa setelah diberikan intervensi (penyuluhan jajanan sehat). Untuk mengetahui apakah peningkatan sikap tersebut signifikan atau tidak maka dilakukan uji paired sample $\mathrm{t}$ test dan diperoleh hasil $\mathrm{p}$-value $(0,000)$ sehingga terdapat perbedaan sikap sebelum dan setelah penyuluhan jajanan sehat.

Penelitian serupa pernah dilakukan oleh Meriana (2019) peningkatan nilai sikap pada responden rata-rata mengalami peningkatan yang lebih besar terjadi pada kelompok eksperiment dibandingkan dengan rata-rata nilai sikap siswa yang mengalami peningkatan pada kelompok kontrol. Selisih peningkatan nilai sikap pada kelompok eksperiment lebih besar yaitu sebanyak 16,63.

Penelitian serupa pernah dilakukan oleh Handayani et al., (2019) yang menyatakan bahwa dari 20 orang responden yang diberikan intervensi bermain ular tangga menunjukkan terjadi peningkatan tingkat kooperatif antara sebelum dan setelah dilakukan permainan ular tangga. Hasil tersebut menunjukkan bahwa pemberian terapi bermain ular tangga diantaranya dapat membantu anak-anak menjadi lebih bertanggung jawab atas perilaku yang dilakukannya dan mengembangkan solusi baru dan kreatif untuk masalah yang anak hadapi.

\section{Pengaruh Permainan Ular Tangga terhadap Pengetahuan dan Sikap Anak Sekolah tentang Makanan Jajanan Sehat}

Hasil penelitian menunjukkan bahwa dengan menggunakan uji statistik diperoleh nilai $\mathrm{p}=0,000<0,05$, adanya pengaruh penyuluhan permainan ular tangga tentang makanan jajanan sehat terhadap pengetahuan dan sikap pada anak sekolah dasar. Berdasarkan hasil pretest dan posttest terhadap 54 siswa, didapat rata-rata perubahan pengetahuan sebelum intervensi sebesar 12,8 dan sesudah intervensi sebesar 15,5, dan perubahan sikap rata-rata sebelum intervensi sebesar 10,2 dan sesudah intervensi sebesar 12,8 .

Berdasarkan hasil data yang didapatkan bahwa adanya peningkatan penyuluhan dengan menggunakan permainan ular tangga tentang pengetahuan siswa sebelum dan sesudah diberinya media tersebut. Sebelum diberinya penyuluhan dengan menggunakan media ular tangga, masih banyak siswa yang belum mengetahui informasi tentang makanan jajanan sehat, hal ini dikarenakan siswa kurangnya informasi yang diberikan dari keluarga maupun sekolah pentingnya mengkonsumsi makanan yang sehat dan menghindari 
makanan yang tidak sehat.

Sejalan dengan penelitian yang dilakukan Handayani et al., (2019) ada pengaruh pendidikan kesehatan dengan metode bermain ular tangga terhadap pengetahuan remaja tentang dampak perkawinan anak.

Hasil tersebut juga ditemukan pada penelitian yang dilakukan oleh Safitri (2017) pada remaja SMP di Tulungagung, dimana terdapat perubahan nilai pengetahuan pada kelompok perlakukan setelah diberikan edukasi dengan media bermain ular tangga. Hal ini disebabkan karena responden sangat antusias pada saat edukasi dan pada saat diskusi bersama dan merasa mudah memahami materi yang diberikan karena merasa tertarik dengan media ular tangga dan senang bisa berdiskusi dengan peserta lain.

Hal ini sejalan dengan hasil penelitian lain yang dilakukan oleh Siregar (2018) pada siswa/I SMA di Kota Semarang, mengatakan bahwa adanya peningkatan pengetahuan sesudah intervensi dikarenakan responden tidak sekedar diberikan materi saja tetapi diajak berdiskusi sembari melakukan permainan ular tangga bersama teman sekelompok, sehingga secara langsung dapat meningkatkan pengetahuan responden.

Hal ini sejalan dengan penelitian yang dilakukan oleh Dewi (2018) pada remaja, bahwa penggunaan media dan metode pembelajaran yang sesuai dengan usia responden memberikan dampak positif terhadap kemudahan penangkapan dan pemahaman materi atau informasi yang diberikan sehingga dapat meningkatkan pengetahuan remaja setelah diberikan intervensi.

Sejalan dengan penelitian Nur'aini \& Ila (2019) yang menunjukkan bahwa sesudah diberikan pendidikan kesehatan dengan media permainan ludo pengetahuan siswa tentang jajanan sehat sebagian besar meningkat dalam kategori baik. Pengetahuan sesudah dilakukan pendidikan kesehatan meningkat skor rataratanya disebabkan dengan permainan yang menyenangkan pengetahuan atau informasi yang diberikan dapat lebih menarik. Pengetahuan yang paling banyak meningkat menjadi baik pada siswa umur 10 tahun dan jenis kelamin laki-laki.

\section{SIMPULAN}

Skor pengetahuan siswa dengan kategori tinggi sebelum intervensi sebesar 21 siswa dan sesudah intervensi 51 siswa. Skor sikap siswa dengan kategori baik sebelum intervensi sebesar 46 siswa dan sesudah intervensi 54 siswa.

Hasil statistik menunjukkan adanya pengaruh permainan ular tangga tentang makanan jajanan sehat terhadap pengetahuan dan sikap pada siswa SD Swasta Muhammadiyah Di Kecamatan Lubuk Pakam.

\section{SARAN}

Berdasarkan penelitian dan pembahasan mengenai "Permainan Ular Tangga Tentang Makanan Jajanan Sehat Dapat Meningkatkan Pengetahuan Dan Sikap Pada Siswa Sd Swasta Muhammadiyah Di Kecamatan Lubuk Pakam. Penulis menyampaikan saran bagi penelitian selanjutnya diharapkan dapat mengkolaborasikan kedua permainan dengan terapi permainan lainya seperti ludo, playstation dan lainnya dengan berbagai tingkat usia pada rentang anak uisa sekolah. 


\section{DAFTAR PUSTAKA}

Agustini, N. P., Kusumajaya, I. G. ., \& Puryana, S. (2019). Pelatihan Pengolahan Jajanan Sehat Anak Sekolah kepada UMKM Makanan Jajanan di Kecamatan Ubud Kabupaten Gianyar. Jurnal Pengabmas Masyarakat Sehat, 1(2), 73-80

Dewi, S. U. (2018). Efektivitas Penyuluhan Kesehatan Reproduksi terhadap Pengetahuan dan Sikap Remaja. Jurnal Ilmiah Keperawatan Orthopedi, 2(2). https://ejournal.akperfatmawati.ac.id

Handayani, S., Monika, R., \& Priska, P. (2019). Efektivitas Penkes dengan Metode Ular Tangga terhadap Pengetahuan Remaja tentang Dampak Perkawinan Anak di SMPN 2 Gunungkidul Yogyakarta. Caring: Jurnal Keperawatan, 8(2), 68-76. https://ejournal.poltekkesjogja.ac.id/index.php/caring/article/view/524

Meriana, B. (2019). Pengaruh Media Komik untuk Peningkatan Pengetahuan dan Sikap dalam Pemilihan Jajanan Sehat. Pontianak Nutrition Journal (PNJ), 2(1), 20. https://doi.org/10.30602/pnj.v2i1.480

Nur'aini, W., \& Ila, A. (2019). Pengaruh Pendidikan Kesehatan dengan Menggunakan Media Permainan Ludo Terhadap Peningkatan Pengetahuan Jajanan Sehat di Desa Candirejo Ungaran Barat. Universitas Ngudi Waluyo

Nur, A., \& Duanita, H. M. (2019). Dampak Penyuluhan Jajanan Sehat terhadap Pengatahuan dan Sikap Anak Sekolah Dasar di Madrasah Ibtidaiyah Al- Fitra Kampung Nelayan Oesapa Kupang. CHMK Health Journal, 3(3), 62-68. https://doi.org/10.1017/CBO9781107415324.004

Oktaviani, E., Ardianty, S., \& Dekawaty, A. (2020). Pengaruh Metode Permainan Acak Kartu terhadap Perilaku Jajanan Makanan Sehat pada Anak Sekolah Dasar Negeri 144 Palembang. Jurnal Hospital Science, 4(1), 33-41. journal.stikesmuhbojonegoro.ac.id/index.php/JHS/article/view/144/99

Olin, V., Keraman, B., Maydinar, D., \& Eca, E. (2020). Pengaruh Terapi Bermain (Skill Play) Permainan Ular Tangga terhadap Tingkat Kooperatif Selama Menjalankan Perawatan pada Anak Prasekolah (3-6 Tahun) Di Ruang Edelweist Rsud Dr. M Yunus Bengkulu. Journal of Nursing and Public Health, 8(1), 111-116. https://doi.org/https://doi.org/10.37676/jnph.v8i1.1008

Rizqi, E. R., \& Sartika, Y. (2020). Pengaruh Media Tebak Gambar terhadap Pengetahuan Jajanan Sehat Siswa SDN 001 Teratak Kabupaten Kampar. Jurnal Kesehatan Masyarakat, 4(1), 58-62

Rosita, W. (2017). Pengaruh Pendidikan Keamanan Jajanan Menggunakan Media Komik terhadap Pengetahuan Gizi Siswa SDN 003 Bangkinang Kota. Institut Pertanian Bogor

Safitri, A. N. (2017). Pengaruh Edukasi dengan Media Ular Tangga terhadap Pengetahuan dan Sikap Remaja dalam Upaya Pencegahan Seks Pranikah di SMPN 1 Besuki Tulungagung. Universitas Airlangga

Septiana, P., \& Suaebah, S. (2019). Edukasi Media Kartu Bergambar Berpengaruh terhadap Pengetahuan dan Sikap Anak dalam Pemilihan Jajanan Sehat di SD Negeri Pontianak $\begin{array}{llll}\text { Utara. Pontianak Nutrition Journal } & \text { (PNJ), } & \text { 1(2), }\end{array}$ https://doi.org/10.30602/pnj.v1i2.288 
Siregar, D. (2018). Evaluasi Efektivitas Permainan Ular Tangga HIV/AIDS terhadap Peningkatan Pengetahuan tentang HIV/AIDS pada Siswa Sma di Kota Semarang. Jurnal Kesehatan Masyarakat (E-Journal), 6(2), 170-178

Suryaningsih, D., \& Naviati, E. (2019). The Effect of Health Education with the Ladder Snake Game Media Against Children's Behavior in Choosing Snack in SD Negeri Bulusan Kecamatan Tembalang. Media Keperawatan Indonesia, 2(2), 6. https://doi.org/10.26714/mki.2.2.2019.6-11 